\title{
A case report of complete pathological remission after chemotherapy in a patient with primary renal squamous cell carcinoma
}

\author{
Haiming Yu, Lan Yu, Jinying Li, Yu Wang, Li Liu, Xiaotao Zhang, Xiaona Han, Xi Cheng \\ Day Ward of Chemotherapy, Qingdao Central Hospital, Qingdao, China \\ Correspondence to: Xiaotao Zhang. Day ward of chemotherapy, Qingdao Central Hospital, Qingdao 266042, China. Email: SABR@VIP.163.com.
}

\begin{abstract}
This is the first case report of the outcomes of systemic chemotherapy in a patient with locally advanced renal squamous cell carcinoma, a rare tumor, as well as the first next generation sequencing study of this rare tumor. The patient's main symptoms were fever and low back pain. Initial positron emission tomography and computed tomography (PET-CT) suggested a malignant renal tumor at onset, but biopsy confirmed renal squamous cell carcinoma. Next generation sequencing showed a low level of microsatellite instability (MSI-L), a high tumor mutational burden (TMB-H), a high neoantigen burden (TNB-H), and a strong loss of heterozygosity (LOH) for human leukocyte antigen (HLA), with 67 deleterious mutations. The patient achieved partial radiological remission after a cycle of systemic chemotherapy with albuminbound paclitaxel combined with nedaplatin. After radical resection of the left renal tumor, postoperative pathology confirmed complete tumor remission and tumor-like xanthogranulomatous pyelonephritis. Conclusion: This renal squamous cell carcinoma patient responded to systemic chemotherapy with paclitaxel combined with platinum, providing a reference for the future treatment of similar cases. Pathology and gene sequencing indicated that renal squamous cell carcinoma occurred in a background of active inflammation and that the tumor evolved immune escape mechanisms such as loss of HLA heterozygosity, with gene repair defects and TMB-H.
\end{abstract}

Keywords: Renal squamous cell carcinoma; chemotherapy; case report; next generation sequencing

Submitted Aug 10, 2020. Accepted for publication Feb 20, 2021.

doi: $10.21037 /$ tau-20-1483

View this article at: http://dx.doi.org/10.21037/tau-20-1483

\section{Introduction}

Renal squamous cell carcinoma (SCC), a rare urinary tumor, accounts for $0.5 \%$ to $8 \%$ of all renal and ureteral tumors (1-6). SCC of urothelial tract is thought to arise through a process of squamous metaplasia of urothelium (7). It may be triggered by chronic irritation and infection such as polycystic kidney disease (7), prolonged use of immunosuppressants $(8,9)$, chronic inflammation (10-18), kidney stones (19-29), and horseshoe kidney (25,30-34). Early symptoms are atypical including recurrent urinary infections, ongoing pyuria, hematuria or backache. Renal squamous cell carcinoma can be easily missed on computed tomography (CT) or B mode ultrasound due to a lack of characteristic manifestations. Given the invasive nature of the disease, the tumor rapidly invades local structures. As a result, patients are usually in the late stage at the time of diagnosis, with an adverse prognosis. 5 -year survival rate for lower and renal pelvis SCC patients was reported to be $18 \%$ with overall median survival of 7.25 months (35).

Renal squamous cell carcinoma is a rare tumor, and no standard of care has been established. Radical nephrectomy with lymph node dissection can be curative in an early stage disease (19). And there is no sufficient evidence for adjuvant chemotherapy and radiotherapy. To date, there is only two reports on postoperative adjuvant therapy. One reported a renal pelvis squamous cell carcinoma patient received adjuvant chemotherapy including paclitaxel and carboplatin after nephrectomy and he was disease free at the 6-month 


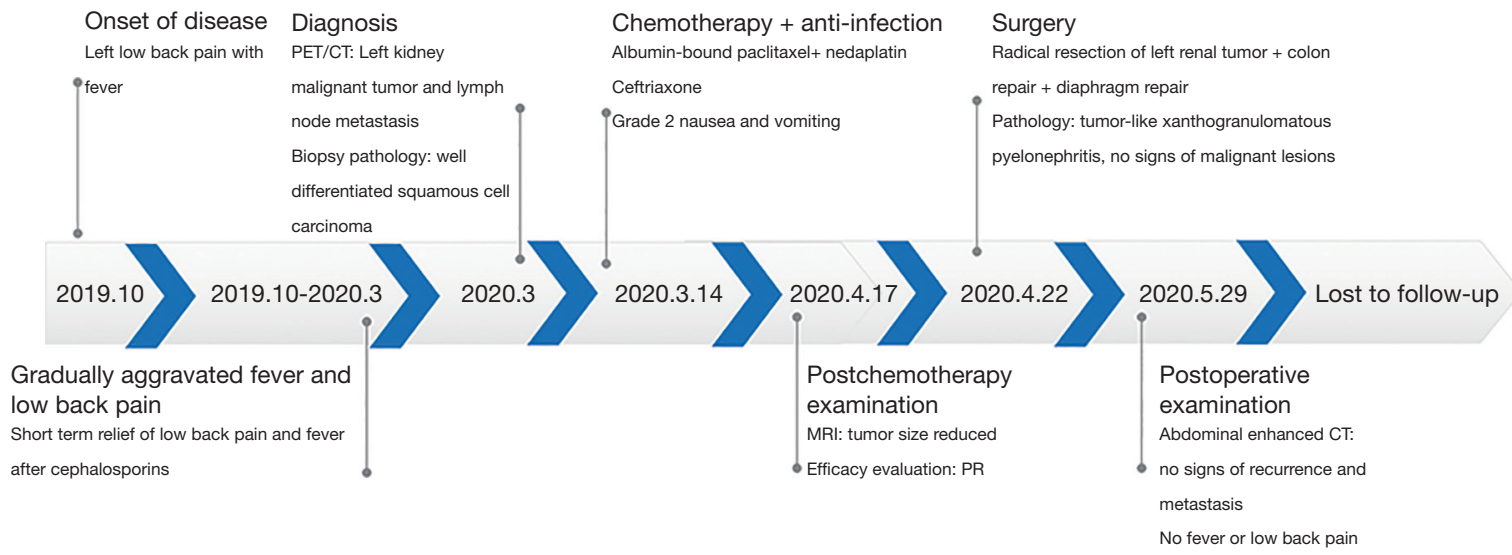

Figure 1 Diagnosis and treatment timeline.

follow-up (7). The other reported two upper urinary tract SCC cases who underwent radio-chemotherapies after surgeries. One of the patients undergoing radiochemotherapy (five cycles of 5-FU and 50 Gy of external beam radiation) survived 87 months and was disease-free at follow up (35).

There are no reports on chemotherapy in the late stage. In this report, the patient had locally advanced renal squamous cell carcinoma. After next generation sequencing, the patient underwent a cycle of preoperative neoadjuvant chemotherapy and achieved partial radiological remission. After surgical resection, postoperative pathology confirmed complete remission. This is the first case report of chemotherapy outcomes in a patient with renal squamous cell carcinoma, as well as the first next generation sequencing study of this rare tumor. We present the following case in accordance with the CARE reporting checklist (available at http://dx.doi.org/10.21037/tau-20-1483).

\section{Case description}

All procedures performed in studies involving human participants were in accordance with the ethical standards of the institutional and/or national research committee(s) and with the Helsinki Declaration (as revised in 2013). Written informed consent was obtained from the patient for publication of this manuscript and any accompanying images.

The patient was a 64-year-old male. He had no history of smoking or drinking. He had type 2 diabetes for more than 10 years and had been taking metformin and gliquidone (no prescriptions). Laboratory tests showed the following: fasting blood glucose, $7-8 \mathrm{mmol} / \mathrm{L}$; glycosylated hemoglobin, $9.3 \%$. He had coronary heart disease for a year but did not receive any treatment. His mother had lung cancer.

Since November 2019, he had intermittent left lower back pain with intermittent irregular fever (mostly in the afternoon or at night, once every 3 to 7 days, up to $38.5^{\circ} \mathrm{C}$; oral paracetamol was effective). He had no frequent urination, urgency, or urination pain and had normal urine color and clarity. He was diagnosed with right orchitis in January 2020, and his fever and low back pain improved after cephalosporin treatment. In February 2020, he had recurrent fever (up to $39^{\circ} \mathrm{C}$, once every 1-3 days), with worsening low back pain.

He visited our hospital on March 2, 2020.

\section{Physical examination upon admission}

The results of the exam were as follows: Eastern Cooperative Oncology Group (ECOG) performance status (PS) score, 1; low back pain numerical rating scale (NRS) score, 3; and left kidney area percussion pain $(+)$. No other abnormalities were found.

\section{Timeline}

The treatment timeline is shown in Figure 1.

\section{Diagnostic process}

\section{Imaging studies (Figure 2)}

On March 1, 2020, abdominal computed tomography (CT) showed a left renal mass that infiltrated the pancreatic tail 

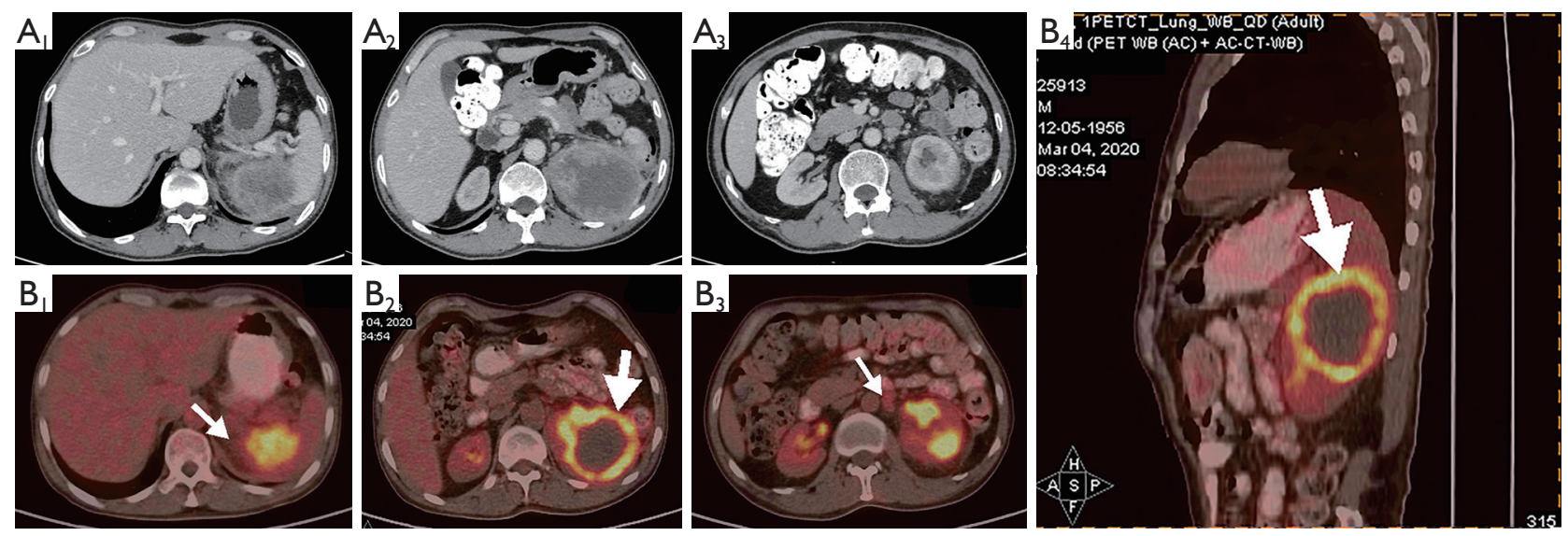

Figure 2 Baseline abdominal CT and PET/CT. (A1, A2, A3) 2020-3-1, Abdominal CT: a space-occupying mass is seen in left kidney, along with the involvement of the tail of the pancreas and the spleen and the enlargement of lymph nodes in retroperitoneal space. (B1, B2, B3, B4) 2020-3-4, PET/CT: hypermetabolic space-occupying lesions (arrows) in left kidney, renal pelvis, and upper ureter are suspected to be malignant (affecting pancreas body/tail and spleen) and retroperitoneal lymph node metastases. A irregular soft tissue density mass sized $8.8 \mathrm{~cm} \times 7.5 \mathrm{~cm}$, with a Ct value of about $38 \mathrm{Hu}$, is visible in left kidney. A ring-shaped increase in 18 F-FDG uptake was observed (the SUVmax was 9.7, and the delayed SUVmax two hours after drug injection was 11.6). A 5.5-cm low-density area is seen in the center, where the FDG metabolism was attenuated (necrosis was considered). The lesion involves the renal pelvis and the upper part of the ureter, and its boundaries with the body and tail of the pancreas and the spleen are unclear. The left perirenal fascia is thickened; the perirenal fat space is turbid, with increased density; and FDG uptake is slightly increased (SUVmax, 2.4). Multiple lymph nodes with shortest diameters smaller than $1.2 \mathrm{~cm}$ are found in retroperitoneum, with increased FDG metabolism (SUVmax, 3.0). Small nodules (with shortest diameters smaller than $0.56 \mathrm{~cm}$ ) are seen on the left clavicle, with slightly increased FDG uptake (SUVmax, 2.1). CT, computed tomography; PET, positron emission tomography; 18F-FDG, 18 fluorine-fluorodeoxyglucose; SUVmax, maximal standard uptake value.

and the spleen, with enlarged retroperitoneal lymph nodes.

On March 4, 2020, positron emission tomography (PET)/CT showed a hypermetabolic mass in the left kidney, renal pelvis, and upper ureter, suggesting a malignant tumor that infiltrated the pancreatic body and tail and the spleen, with retroperitoneal lymph node metastasis.

\section{Laboratory tests}

The urine analysis results were as follows: nitrite (-), protein $(3+)$, occult blood (3+), white blood cell (1+), and cast (-).

The urine smear result was as follows: Gram staining (-); the urine culture result was as follows: no bacterial growth.

Blood test results were as follows: normal white blood cell $\left(13.12 \times 10^{9} / \mathrm{L}\right)$ and neutrophil $\left(9.02 \times 10^{9} / \mathrm{L}\right)$ counts and moderate anemia (hemoglobin (HGB) $120 \mathrm{~g} / \mathrm{L}$ ).

C-reactive protein (CRP) was significantly elevated (76.08 mg/L).

Mild renal dysfunction [blood urine nitrogen (BUN), $11.6 \mathrm{mmol} / \mathrm{L}$; creatinine (CREA), $188 \mu \mathrm{mol} / \mathrm{L}]$ was noted, with an estimated glomerular filtration rate of
$26.85 \mathrm{~mL} / \mathrm{min} / 1.73 \mathrm{~m}^{2}$.

For serum tumor biomarkers, squamous cell carcinoma antigen (SCCA) $(19.30 \mathrm{ng} / \mathrm{mL})$, cancer antigen 12-5 (CA12-5) (41.02 U/mL), cytokeratin fraction (CYFRA) $(11.98 \mathrm{ng} / \mathrm{mL})$, and progastrin-releasing peptide (proGRP) $(81 \mathrm{pg} / \mathrm{mL})$ were all significantly elevated.

\section{Biopsy and pathological diagnosis}

On March 6, 2020, the patient underwent CT-guided biopsy of the left renal mass (Figure 3).

\section{Pathological findings (reviewed by a pathologist from another class A tertiary hospital) (Figure 4)}

Infiltration of a well-differentiated squamous cell carcinoma with apparent keratinization was noted. No signs of urothelial carcinoma or renal cell carcinoma were noted. Given limited biopsy samples, possible diagnoses were 1) urothelial carcinoma with significant squamous differentiation and 2) primary squamous cell carcinoma.

Figure 5 shows programmed death ligand 1 (PD-Ll 




Figure 3 CT-guided intraoperative puncture biopsy of the space-occupying lesion in left kidney. Based on PET/CT finding, biopsy is performed in the hypermetabolic area around the tumor.

22C3) immunohistochemistry, tissue polypeptide specific antigen (TPS) (60-70\%), and carbamoyl phosphate synthetase (CPS) [75].

\section{Next generation sequencing}

Next generation sequencing revealed the following: a low level of microsatellite instability (MSI-L) (9.52\%); a high tumor mutational burden (TMB-H) (76.40 MutS/Mb); a high neoantigen burden (TNB-H) (17.42 Neos/Mb); a strong loss of heterozygosity (LOH) for human leukocyte antigen (HLA); tumor protein 53 (TP53) K352*, 24.30\%; MutS homolog 2 (MSH2) Q419L, 17.2\%; breast cancer 2 (BRCA2) R155*, 28.94\%; checkpoint kinase 2 (CHEK2) S192L, 18.85\%; and CHEK2 S187C, 19.83\%, with 67 deleterious mutations.

\section{Diagnosis}

The diagnosis was as follows: left renal well-differentiated squamous cell carcinoma, stage cT4N2M0 IV.

\section{Treatment}

\section{Surgical evaluation}

The patient was temporarily contraindicated for surgery due to the locally advanced nature of his tumor.

\section{Other treatments}

The following treatment was administered: antiinfection

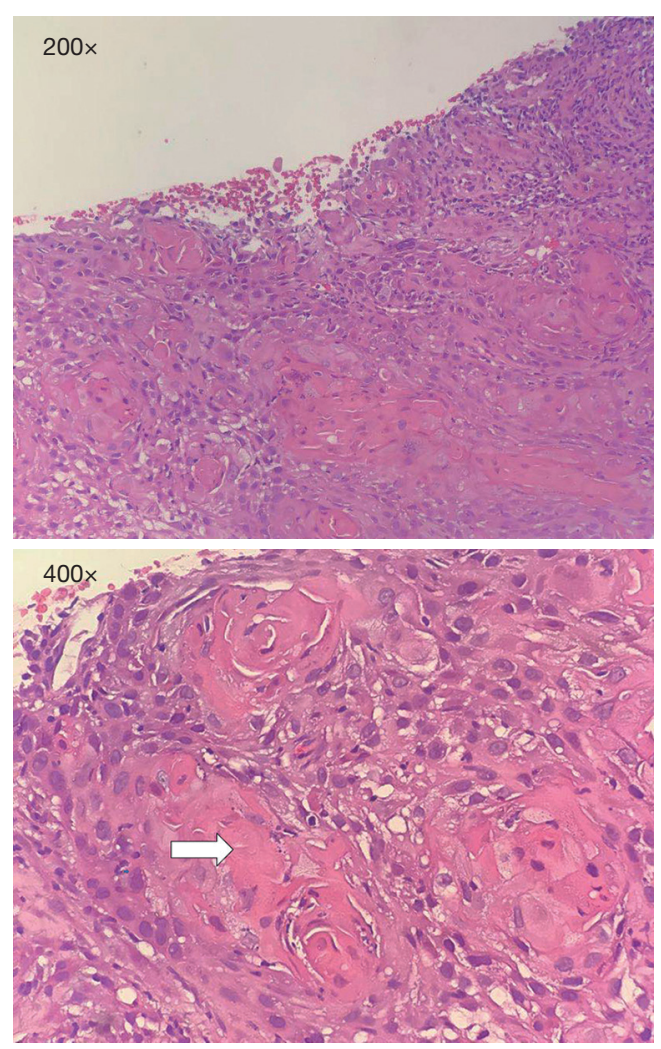

Figure 4 Pathological assessment of HE-stained sections. The well-differentiated squamous cell carcinoma is obviously keratinized (indicated with white arrow). No urothelial carcinoma or renal cell carcinoma component was found in the section. HE, hematoxylin-eosin.

treatment with ceftriaxone for 2 weeks + symptomatic nutritional support (enteral nutrition, anticoagulation) + antipyretic treatment.

\section{Systemic chemotherapy}

From March 14, 2020, the patient received albumin-bound paclitaxel (200 mg on day 1, $100 \mathrm{mg}$ on day 6) and nedaplatin (60 mg on days 1-2). He experienced grade 2 nausea and vomiting. No bone marrow suppression or neurotoxicity was observed. He still had intermittent fever (once every 3-7 days, up to $38.5^{\circ} \mathrm{C}$; oral paracetamol was effective). His low back pain improved slightly (NRS score 1-2).

\section{Postchemotherapy examination}

On April 17, 2020, magnetic resonance imaging (MRI) 

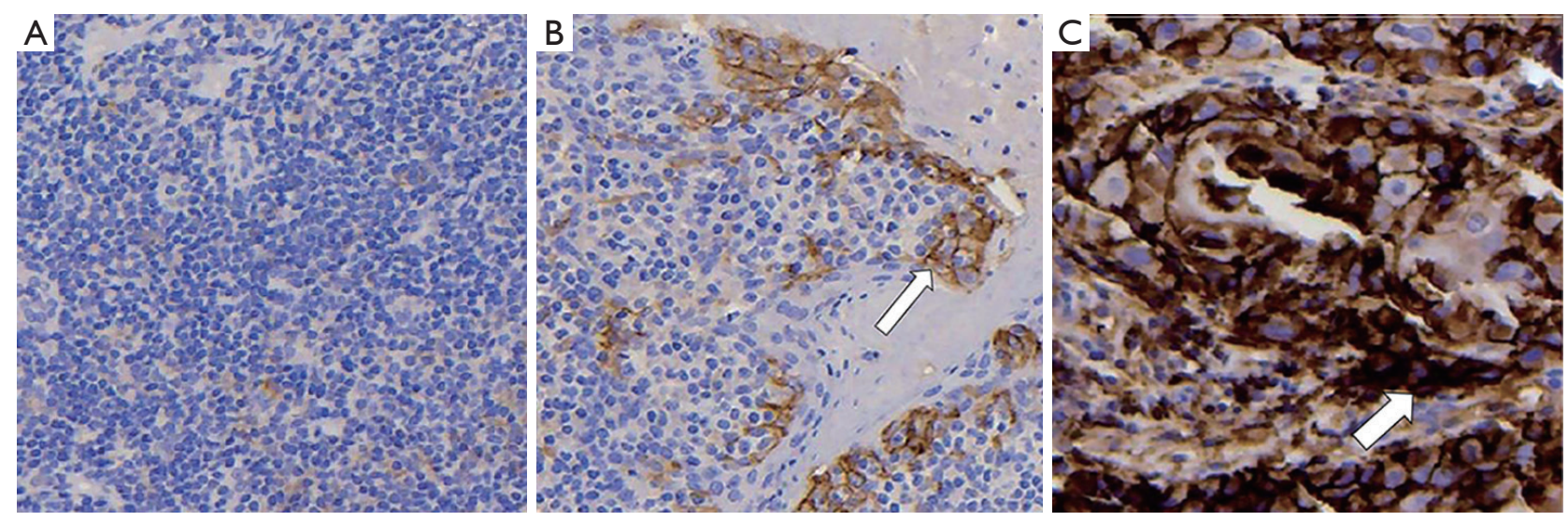

Figure 5 PD-L1 (DAKO 22C3) immunohistochemistry. (A) Negative control; (B) positive control; (C) immunohistochemistry of tumor tissue: TPS 60-70\% and CPS 75 (indicated with white arrows). PD-L1, programmed death-ligand 1; TPS, tumor proportion score; CPS, combined positive score.
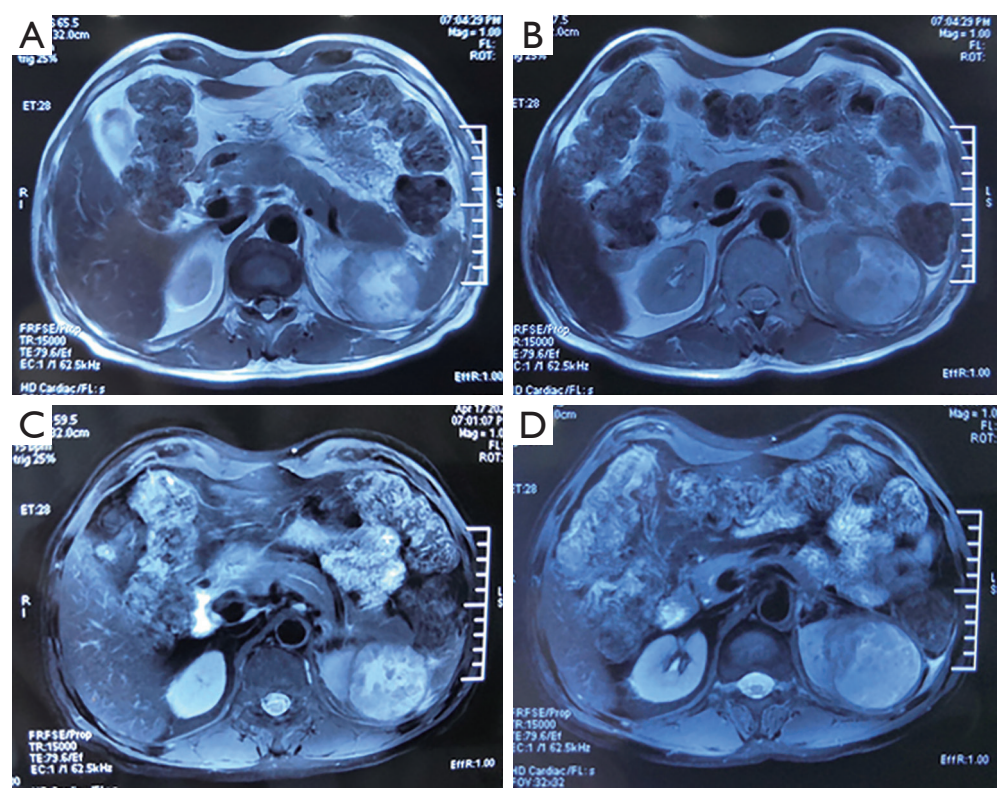

Figure 6 Abdominal MRI findings one month after chemotherapy. MRI on April 17, 2020 showed that the tumor markedly shrank (maximum diameter, $5.5 \mathrm{~cm}$ ), which met the criteria for partial remission. MRI, magnetic resonance imaging.

showed that the tumor had reduced significantly (maximum diameter $5.5 \mathrm{~cm}$ ), indicating partial remission (Figure 6). No bacterial growth was observed (urine culture). Urologists evaluated the tumor as resectable at that time. And surgical treatment was scheduled.

\section{Surgical treatment}

On April 22, 2020, the patient underwent radical resection of left renal tumor + colon repair + diaphragm repair. Intraoperative exploration showed adhesion between the left kidney and the surrounding tissue, spleen, colon, diaphragm, pancreas, and adrenal gland. The left adrenal gland was also removed.

\section{Postoperative pathology}

The following findings were noted: tumor-like xanthogranulomatous pyelonephritis; no signs of malignant 

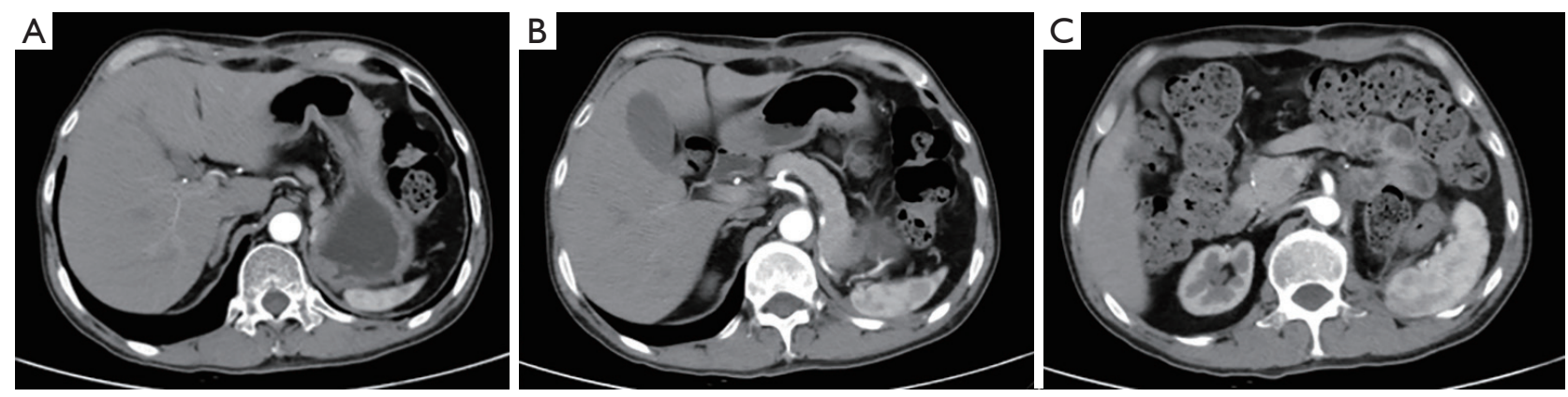

Figure 7 Abdominal CT after surgery. Contrast-enhanced CT of the abdomen on May 29, 2020 showed no sign of tumor recurrence/ metastasis.

lesions; reactive hyperplasia of 2 lymph nodes at the left renal hilum; significant necrosis and amorphous material deposition and calcification in the renal parenchyma, with scattered keratinization; infiltration of a large number of tissue cells, multinucleated giant cells, and lymphocytes; significant glomerulus and tubular sclerosis; significant infiltration of chronic inflammatory cells; and significant thickening of the intima of small blood vessels in the renal parenchyma.

\section{Postoperative laboratory tests}

Amylase and lipase were significantly elevated, with an estimated glomerular filtration rate of $27-34 \mathrm{~mL} / \mathrm{min} / 1.73 \mathrm{~m}^{2}$.

\section{Postoperative follow-up}

On May 29, 2020, enhanced abdominal CT showed no signs of tumor relapse or metastasis (Figure 7).

Blood test results were as follows: normal white blood cell $\left(5.63 \times 10^{9} / \mathrm{L}\right)$ and neutrophil $\left(3.46 \times 10^{9} / \mathrm{L}\right)$ counts and mild anemia (HGB $120 \mathrm{~g} / \mathrm{L}$ ).

CRP was normal $(1.21 \mathrm{mg} / \mathrm{L})$.

Urine analysis results were normal.

There was mild renal dysfunction (BUN, $12.1 \mathrm{mmol} / \mathrm{L}$; CREA $193 \mu \mathrm{mol} / \mathrm{L}$ ), with an estimated glomerular filtration rate of $29.44 \mathrm{~mL} / \mathrm{min} / 1.73 \mathrm{~m}^{2}$.

For peripheral blood biomarkers, mildly elevated SCCA (4.0 ng/mL; normal range: $0-2.5 \mathrm{ng} / \mathrm{mL}$ ), normal CA12-5 (22.24 U/mL), mildly elevated CYFRA $(4.21 \mathrm{ng} / \mathrm{mL}$; normal range: $0-3.3 \mathrm{ng} / \mathrm{mL})$, and elevated PROGRP $(81 \mathrm{pg} / \mathrm{mL})$ were observed.

The patient was followed up through telephone consultations until January 2021. He reported no discomfort. CT scan on $27^{\text {th }}$ January 2021 of the chest and abdomen found no sign of recurrence. The post-operative disease free survival was 9 months.

\section{Discussion}

Renal squamous cell carcinoma is rare and is associated with chronic inflammation due to renal stones or chronic infection. There have been only 2 previous reports of 3 cases of xanthogranulomatous pyelonephritis with renal squamous cell carcinoma $(14,18)$. In this report, the patient presented similar clinical manifestations as those in previous reports $(14,18,36)$, including initial symptoms of urinary infection (fever, low back pain), elevated peripheral blood white blood cell and neutrophil counts with moderate anemia, elevated CRP, and urine white blood cells and occult blood. After surgery, the clinical symptoms disappeared, and blood test results, urine analysis results, and CRP level returned to normal.

Xanthogranulomatous pyelonephritis is a rare chronic renal inflammatory disease. It is related to inflammatory disorders associated with defects in the ability of macrophages to degrade bacteria as well as with chronic obstruction, stones, and infections $(36,37)$. Some case reports have shown that antibiotic treatment is effective $(38,39)$. In this report, the patient showed no signs of obstruction or stones. Pretreatment blood tests and urine analysis suggested infection; however, no bacterial growth was observed in urine culture (twice). This may be due to invalid urine samples, lack of bacterial infection, or infection with L-form bacteria with a defective cell wall (difficult to detect with routine culture). The clinical manifestations indicated significant renal inflammation, and thus bacterial infection could not be ruled out. After a comprehensive evaluation, the patient was given antiinfection treatment 
with cephalosporin in addition to chemotherapy.

Nejman et al. (40) conducted an exploratory study of the tumor microbiome in a large sample of solid tumors and found that live bacteria were widely present in tumor cells, including brain tumor cells and bone tumor cells, and in macrophages within the tumor microenvironment. These bacteria lose their cell wall and become L-form bacteria and can decompose and utilize tumor metabolites. Further research is needed to investigate the effect of these bacteria on tumor metabolism and the immune microenvironment (41). Due to limited conditions, we were unable to investigate bacterial infection in the tumor or the role of bacterial infection in tumor development and progression in this patient, representing limitations of this case report.

For this patient, preoperative PET/CT showed findings similar to those in previous reports of renal squamous cell carcinoma. The tumor tissue is hypermetabolic and highly invasive. Both PET/CT and postoperative pathology showed significant necrosis in the center of the tumor. We collected a biopsy sample from the hypermetabolic region (per PET/CT) to confirm the diagnosis, demonstrating the important role of PET/CT in the diagnosis of renal squamous cell carcinoma.

Radical nephrectomy with lymph node dissection is the mainstay for treating early stage renal pelvis SCC and can be curative (19). There has been only two reports of three cases of chemotherapy on renal pelvis SCC patients $(7,35)$. The evidences of effectiveness of chemotherapy on renal pelvis SCC could not be provided by the two reports since the chemotherapy was given postoperatively. There are no reports on chemotherapy in the late stage so far.

This is the first report of chemotherapy outcomes of a patient with locally advanced renal squamous cell carcinoma. Before surgery, the patient underwent a cycle of chemotherapy with albumin-bound paclitaxel + nedaplatin. He tolerated the treatment well. Imaging studies at 1 month after chemotherapy indicated partial remission, and postoperative pathology confirmed complete remission, providing preliminary evidence of the effectiveness of this chemotherapy regimen for renal squamous cell carcinoma. Pretreatment laboratory tests indicated renal dysfunction, a decreased glomerular filtration rate, and stage 4 chronic kidney disease. No significant change was observed in renal function after chemotherapy and surgery, indicating that a cycle of chemotherapy had no significant effect on renal function. We deduce that the patient also had right renal dysfunction, even though there was no imaging abnormality. The patient was scheduled for further evaluation of right kidney function after surgery, but the patient refused the evaluation.

This is also the first next generation sequencing and immune study of renal squamous cell carcinoma. HLA$\mathrm{LOH}$ is an effective mechanism of tumor immune escape. Under the pressure of active antitumor immunity, tumor cells undergo clonal selection to form HLA-LOH clones. Tumor cells exhibiting HLA-LOH cannot effectively present tumor antigens, impairing $\mathrm{T}$ cell recognition and leading to tumor immune escape and the accumulation of tumor neoantigens. This is the theoretical basis for the coexistence of HLA-LOH and TMB-H/TNB-H in this patient. Moreover, gene sequencing showed mutations in multiple genes related to DNA damage and repair, suggesting a higher risk of DNA replication errors, which further increases TMB/TNB (42). Studies have shown that in the inflammatory microenvironment, tumor cells adapt and express a high level of PD-L1 (43). In this patient, tumor tissue coexisted with xanthogranulomatous pyelonephritis, suggesting active inflammation in the tumor microenvironment, resulting in a high level of PDL1 expression in tumor cells. It is speculated that the evolution process of this case was as follows: chronic renal inflammation led to repeated tissue damage and repair and the development of malignant cells, and then, an active inflammatory microenvironment and antitumor immune environment screened out HLA-LOH clones, with the subsequent increase in TMB and TNB due to immune escape.

The limitations of this case report are as follows: The number of cases in this study is too small, so a larger sample study should be done for verification of the effectiveness and safety of chemotherapy on advanced renal squamous cell carcinoma patients. The follow-up time of this case was short.

Conclusion: This is the first report of the safety and effectiveness of albumin-bound paclitaxel + nedaplatin for the treatment of locally advanced renal squamous cell carcinoma, providing a new basis for the treatment of this rare disease. This is also the first next generation sequencing and PD-L1 immunohistochemistry study of renal squamous cell carcinoma. The results indicate that defects in DNA damage and repair occur in renal squamous cell carcinoma and that active inflammation reactions and immune escape mechanisms exist in the tumor microenvironment.

\section{Patient perspective}

The patient was satisfied with the treatment effect. 


\section{Acknowledgments}

Funding: None.

\section{Footnote}

Reporting Checklist: The authors have completed the CARE reporting checklist. Available at http://dx.doi.org/10.21037/ tau-20-1483

Conflicts of Interest: All authors have completed the ICMJE uniform disclosure form (available at http://dx.doi. org/10.21037/tau-20-1483). The authors have no conflicts of interest to declare.

Ethical Statement: The authors are accountable for all aspects of the work in ensuring that questions related to the accuracy or integrity of any part of the work are appropriately investigated and resolved. All procedures performed in studies involving human participants were in accordance with the ethical standards of the institutional and/or national research committee(s) and with the Helsinki Declaration (as revised in 2013). Written informed consent was obtained from the patient for publication of this manuscript and any accompanying images.

Open Access Statement: This is an Open Access article distributed in accordance with the Creative Commons Attribution-NonCommercial-NoDerivs 4.0 International License (CC BY-NC-ND 4.0), which permits the noncommercial replication and distribution of the article with the strict proviso that no changes or edits are made and the original work is properly cited (including links to both the formal publication through the relevant DOI and the license). See: https://creativecommons.org/licenses/by-nc-nd/4.0/.

\section{References}

1. Blacher EJ, Johnson DE, Abdul-Karim FW, et al. Squamous cell carcinoma of renal pelvis. Urology 1985;25:124-6.

2. Li MK, Cheung WL. Squamous cell carcinoma of the renal pelvis. J Urol 1987;138:269-71.

3. Lee TY, Ko SF, Wan YL, et al. Renal squamous cell carcinoma: CT findings and clinical significance. Abdom Imaging 1998;23:203-8.

4. Holmäng S, Lele SM, Johansson SL. Squamous cell carcinoma of the renal pelvis and ureter: incidence, symptoms, treatment and outcome. J Urol 2007;178:51-6.

5. Booth CM, Cameron KM, Pugh RC. Urothelial carcinoma of the kidney and ureter. Br J Urol 1980;52:430-5.

6. Berz D, Rizack T, Weitzen S, et al. Survival of patients with squamous cell malignancies of the upper urinary tract. Clin Med Insights Oncol 2012;6:11-8.

7. Xie J, Zhang XB, Wang WZ, et al. Case report of renal pelvis squamous cell carcinoma with tumor embolus in autosomal dominant polycystic kidney disease. Medicine (Baltimore) 2016;95:e4597.

8. Jakes A, Jani P, Menon M, et al. Renal Squamous Cell Carcinoma of a Native Kidney After Renal Transplant: A Case Report. Transplant Proc 2016;48:259-61.

9. Nair B, Sukumar S, Poolari GK, et al. Azathioprineinduced squamous cell carcinoma of the kidney. Scand J Urol Nephrol 2007;41:173-5.

10. Kato T, Komatzu Y, Kiyo H. Squamous cell carcinoma of the kidney arising during chemotherapy for renal tuberculosis: report of a case. Hinyokika Kiyo 1971;17:137-40.

11. Obad-Kovačević D, Kardum-Skelin I, Kaić G, et al. Hydronephrotic Kidney Previously Treated for Tuberculosis: Rare Primary Squamous Cell Carcinoma of Renal Pelvis Diagnosed by Fine-needle Aspiration Cytology. Urol Case Rep 2015;3:173-4.

12. Mathur S, Rana P, Singh S, et al. Incidentally detected squamous cell carcinoma in non-functioning kidney presenting as multi-cystic mass. J Surg Case Rep 2011;2011:8.

13. Mardi K, Kaushal V, Sharma V. Rare coexistence of keratinizing squamous cell carcinoma with xanthogranulomatous pyelonephritis in the same kidney: report of two cases. J Cancer Res Ther 2010;6:339-41.

14. Güler Y, Üçpınar B, Erbin A. Renal pyelocalyceal squamous cell carcinoma in a patient with an ectopic kidney presenting with chronic pyelonephritis: a case report. J Med Case Rep 2019;13:154.

15. O'Sullivan DC, Murphy D, Conlon P, et al. Hypercalcaemia due to squamous cell carcinoma in a tuberculous kidney: case report and review of pathogenesis. Br J Urol 1994;73:106-7.

16. Al-Assiri M, Al-Otaibi MF, Sircar K, et al. Renal pelvis squamous cell carcinoma and renal cell carcinoma in a tuberculous kidney. ScientificWorldJournal 2004;4:965-8.

17. Wang Z, Yan B, Wei YB, et al. Primary kidney parenchyma squamous cell carcinoma mimicking xanthogranulomatous pyelonephritis: A case report. Oncol Lett 2016;11:2197-81. 
18. Gilbert JB, Macmillan SF. Cancer of the Kidney: Squamous-Cell Carcinoma of the Renal Pelvis with Special Reference to Etiology. Ann Surg 1934;100:429-44.

19. Hassan M, Qureshi A. Incidental squamous cell carcinoma of the renal pelvis in a non functioning kidney that was missed on two non-contrast Ct-scans. J Ayub Med Coll Abbottabad 2017;29:489-92.

20. Hosseinzadeh M, Mohammadzadeh S. Primary Pure Squamous Cell Carcinoma of Kidney Associated with Multiple Stag Horn Stones. Int Med Case Rep J 2020;13:261-3.

21. Paonessa J, Beck H, Cook S. Squamous cell carcinoma of the renal pelvis associated with kidney stones: a case report. Med Oncol 2011;28 Suppl 1:S392-4.

22. Kumar S, Tomar V, Yadav SS, et al. Primary Squamous Cell Carcinoma of Kidney Associated With Large Calculus in Non-functioning Kidney: A Case Report. Urol Case Rep 2016;8:4-6.

23. Jain A, Mittal D, Jindal A, et al. Incidentally detected squamous cell carcinoma of renal pelvis in patients with staghorn calculi: case series with review of the literature. ISRN Oncol 2011;2011:620574.

24. Ito H, Oishi M, Murase T. A case of squamous cell carcinoma of the renal pelvis originating from a functional solitary kidney associated with renal stones. Hinyokika Kiyo 1988;34:2171-4.

25. Reed HM, Robinson ND. Horseshoe kidney with simultaneous occurrence of calculi, transitional cell and squamous cell carcinoma. Urology 1984;23:62-4.

26. Verma N, Yadav G, Dhawan N, et al. Squamous cell carcinoma of kidney co-existing with renal calculi: a rare tumour. BMJ Case Rep 2011;2011:bcr1020103388.

27. Kalayci OT, Bozdag Z, Sonmezgoz F, et al. Squamous cell carcinoma of the renal pelvis associated with kidney stones: radiologic imaging features with gross and histopathological correlation. J Clin Imaging Sci 2013;3:14.

28. Deng S, Zhang B, Huang Y, et al. Case report of primary renal pelvis squamous cell carcinoma coexisting with longstanding calculi in left kidney on 18F-FDG PET/CT. Medicine (Baltimore) 2017;96:e6341.

29. Charlton CA, Richardson WW. Squamous cell carcinoma of an ectopic kidney with staghorn calculus: case report. $\mathrm{Br}$ J Urol 1966;38:428-31.

30. Mizusawa H, Komiyama I, Ueno Y, et al. Squamous cell carcinoma in the renal pelvis of a horseshoe kidney. Int J Urol 2004;11:782-4.

31. Reed HM, Robinson ND. Horseshoe kidney with simultaneous occurrence of calculi, transitional cell and squamous cell carcinoma. Urology 1984;23:62-4.

32. Imbriaco M, Iodice D, Erra P, et al. Squamous cell carcinoma within a horseshoe kidney with associated renal stones detected by computed tomography and magnetic resonance imaging. Urology 2011;78:54-5.

33. Waltzer WC, Frischer Z, Gonder M. Squamous cell carcinoma in a horseshoe kidney. Int Urol Nephrol 1985;17:115-8.

34. Ashraf SM, Tyagi SP, Ansari BA. Squamous cell carcinoma in a horse-shoe kidney. J Indian Med Assoc 1980;75:222-3.

35. Rausch S, Hofmann R, von Knobloch R. Nonbilharzial squamous cell carcinoma and transitional cell carcinoma with squamous differentiation of the lower and upper urinary tract. Urol Ann 2012;4:14-8.

36. Jha SK, Aeddula NR. Pyelonephritis Xanthogranulomatous. In: StatPearls. Treasure Island (FL): StatPearls Publishing, May 30, 2020.

37. Chlif M, Chakroun M, Ben Rhouma S, et al. Xanthogranulomatous pyelonephritis presenting as a pseudotumour. Can Urol Assoc J 2016;10:E36-40.

38. Fitouri Z, Nouira Y, Nouira K, et al. Focal xanthogranulomatous pyelonephritis: success of conservative treatment. A case report. Tunis Med 2008;86:912-5.

39. Ho CI, Wen YK, Chen ML. Xanthogranulomatous pyelonephritis successfully treated with antibiotics only. J Chin Med Assoc 2008;71:643-5.

40. Nejman D, Livyatan I, Fuks G, et al. The human tumor microbiome is composed of tumor type-specific intracellular bacteria. Science 2020;368:973-80.

41. Atreya CE, Turnbaugh PJ. Probing the tumor micro(b) environment. Science 2020;368:938-9.

42. McGranahan N, Rosenthal R, Hiley CT, et al. AlleleSpecific HLA Loss and Immune Escape in Lung Cancer Evolution. Cell 2017;171:1259-71.e11.

43. Zhao T, Li Y, Zhang J, et al. PD-L1 expression increased by IFN- $\gamma$ via JAK2-STAT1 signaling and predicts a poor survival in colorectal cancer. Oncol Lett 2020;20:1127-34.

Cite this article as: $\mathrm{Yu} \mathrm{H,} \mathrm{Yu} \mathrm{L,} \mathrm{Li} \mathrm{J,} \mathrm{Wang} \mathrm{Y,} \mathrm{Liu} \mathrm{L,} \mathrm{Zhang}$ X, Han X, Cheng X. A case report of complete pathological remission after chemotherapy in a patient with primary renal squamous cell carcinoma. Transl Androl Urol 2021;10(2):9971005. doi: 10.21037/tau-20-1483 